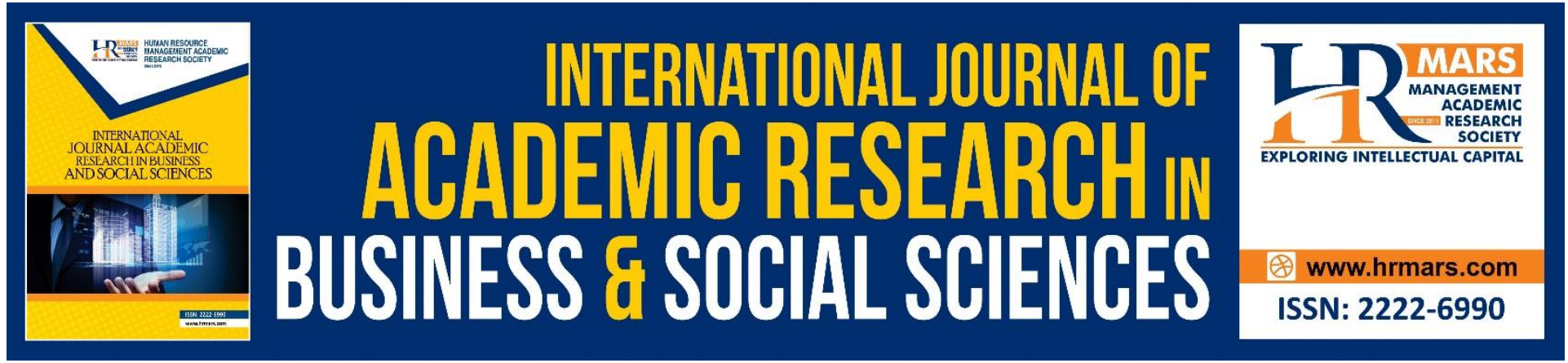

\title{
Assessment of Financial Performance: A Case of some Financial Institutions in Ghana
}

\author{
Mary Ewool, Samuel Owusu Atuahene
}

To Link this Article: http://dx.doi.org/10.6007/IJARBSS/v11-i7/10580

DOI:10.6007/IJARBSS/v11-i7/10580

Received: 22 May 2021, Revised: 25 June 2021, Accepted: 08 July 2021

Published Online: 26 July 2021

In-Text Citation: (Ewool \& Atuahene, 2021)

To Cite this Article: Ewool, M., \& Atuahene, S. O. (2021). Assessment of Financial Performance: A Case of some Financial Institutions in Ghana. International Journal of Academic Research in Business and Social Sciences, 11(7), 1103-1125.

\section{Copyright: (c) 2021 The Author(s)}

Published by Human Resource Management Academic Research Society (www.hrmars.com)

This article is published under the Creative Commons Attribution (CC BY 4.0) license. Anyone may reproduce, distribute, translate and create derivative works of this article (for both commercial and non-commercial purposes), subject to full attribution to the original publication and authors. The full terms of this license may be seen at: http://creativecommons.org/licences/by/4.0/legalcode

Vol. 11, No. 7, 2021, Pg. 1103 - 1125

Full Terms \& Conditions of access and use can be found at http://hrmars.com/index.php/pages/detail/publication-ethics 


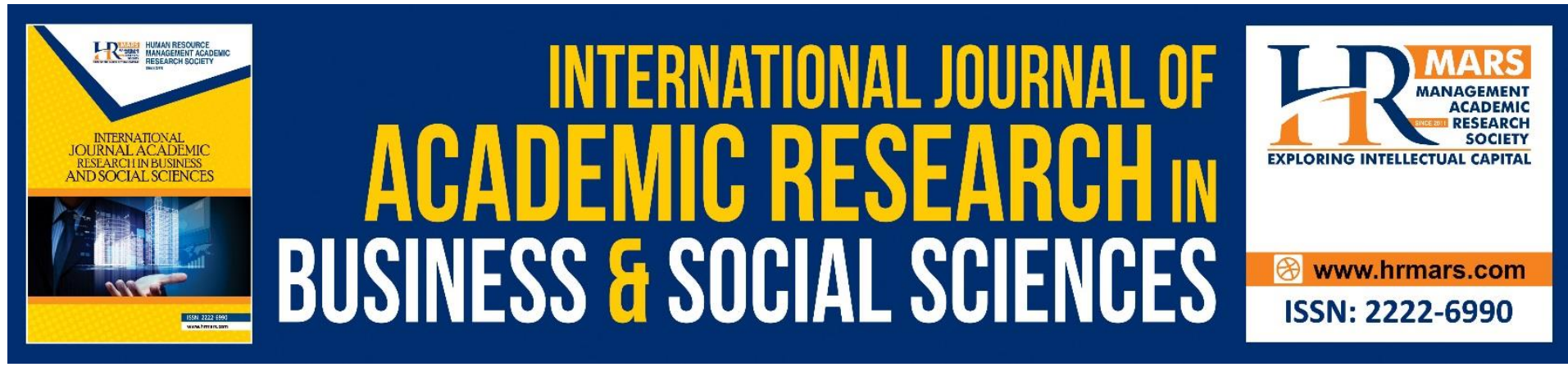

\title{
Assessment of Financial Performance: A Case of some Financial Institutions in Ghana
}

\author{
Mary Ewool, Samuel Owusu Atuahene \\ Institute of Distance Learning and Continuing Education (Idce), Department of \\ Accountancy and Accounting Information Systems, Kumasi Technical University, \\ P. O. Box 854, Kumasi, Ghana \\ Email: ewool.mary@gmail.com
}

\begin{abstract}
Ghana is currently undergoing vigorous financial sector restructuring and some financial institutions (FIs) have been closed down or merged due to poor financial performance. The purpose of the study was to assess the financial performance of some financial institutions in Ghana. Return on Assets (ROA) and Return on Equity (ROE) ratios for measuring the financial performance were calculated from secondary data obtained from $15 \mathrm{Fls}$. The findings of the study revealed that few Fls performed well and made some gains (ROA ratios $\geq 5$ ) in respect to their assets indicating higher net profits $\geq 5$ pesewas per every cedi invested while the rest majority, could not make much profits as far as the usage of assets were concerned. Also, most of the Fls had ROEs $>0.20$ that is $>20$ pesewas per every cedi invested indicating good returns and higher net profits in terms of shareholders investment. It was recommended from the study that, Fls that had low and negative ROAs and ROEs must look at the management efficiency of their Fls and their income generation as against assets and liabilities acquired. The Fls must evaluate and update their objectives from time to time to meet their goals and targets.
\end{abstract}

Keywords: Financial institutions, Financial Performance, Return on Assets, Return on Equity, Investment

\section{Introduction}

A financial institution (FI) may be defined as a company involved in the business of financial and monetary transactions including deposits, loans, investments, and currency exchange etc. The central banks, internet banks, retail and commercial banks, investment banks, savings, and loans associations, credit unions, investment companies, brokerage firms, insurance companies, and mortgage companies form the major categories of financial institutions (Hayes, 2021; Horton, 2021). Banks and Microfinance institutions (MFIs) play crucial roles in financial systems and markets by supporting businesses and connecting investors or depositors with individuals who want loan or assistance in the growth of their businesses and contribute to the economic growth of countries (Bank-news n.d, Boateng \& Agyei, 2013; Boateng, Boateng \& Bampoe, 2015). There are 28 banks in Ghana including 4 with 
representative offices and 319 MFIs that are in compliance with Bank of Ghana regulations (Bank of Ghana, 2018; list of banks in Ghana n.d).

Microfinance institutions in Ghana include: savings and loans companies, rural and community banks, certain development and commercial banks, credit unions, financial nongovernmental institutions, microfinance institutions, cooperatives, clubs, accumulating savings and credit associations, moneylenders etc. (Bank of Ghana, 2011). Since these two major financial institutions (banks and MFIs) play important roles in business financial transactions and economic growth, various stakeholders are very much concerned with the financial performance of these institutions. For example, shareholders may be interested in knowing how their money is invested with profitable returns; Management would have to assess how the Fls perform over the years and compare with their peers in modern competitive financial systems; Regulators may be concerned with the safety and soundness of the banking system especially as insolvencies could result in Fl crises that could lead to its closure ; Depositors may evaluate the Fls as a guarantee of their deposits; The business community and the general public would be interested in Fls performance so as to access credit and other financial services (Benton \& James, 2005; Levine, 2003).

The financial sector in Ghana is currently undergoing vigorous restructuring, which has resulted in the termination of some financial institutions which could not perform up to expectation probably due to poor and inefficient management (Boateng \& Boateng, 2014). Financial performance considers the level of performance of a business over some specified time which is normally expressed as the overall profits and losses during that time (Bragg, 2012). Evaluating the financial performance of a business help stakeholders including Shareholders, Management, Regulators, Depositors, the business community and the general public to assess the outcomes of the strategies employed by the Fls in present day competitive financial systems. Thus, this study was undertaken to assess the financial performance of some financial institutions in Ghana with the following objectives:

- determine how well the financial institution is managing its available resources and assets to net higher profits.

- assess the efficiency of the financial institution on the utilization of equity investments to earn profit for investors.

\section{Literature Review}

This chapter reviews the relevant related literature on financial performance of financial institutions including firm performance definitions, Concept of financial performance in financial Institutions, firm performance importance, financial ratios, importance of financial ratios, advantages of financial ratios, limitations of financial ratios and empirical review.

\section{Firm Performance Definitions}

Performance measurement could be referred to as the process of measuring the actions, efficiency and effectiveness of an organization (Neely, Gregory \& Platts, 1995). Performance measurement may be complex in nature depicting the reality of performance in organized symbols that can be related and relayed under the same circumstances (Lebas, 1995). In the current business management, performance measurement may be considered to play a very critical role (Koufopoulos et al., 2008). Performance management may be described as a process wherein the organization manages its performance to match its corporate and functional strategies and objectives (Bititci, Carrie \& McDevitt, 1997). Furthermore, benefits 
accruing from the firm's shares by the shareholders can be described as the firm's value (Rouf, 2011). The company's performance can be viewed from the financial statement reported by the company

\section{Concept of Financial Performance in Financial Institutions}

The performance of companies may comprise the actual output of the organization as measured against its intended outputs, goals and objectives. Performance may be termed as the degree of achievement of the mission at work place (Cascio 2006). However, different researchers have different thoughts about performance and most of them refer to it as the expression of the range of measurements of transactional efficiency, input and output efficiency (Stannack, 1996). Chenhall (2005) is with the view that performance of an organization can be measured financially, non-financially or both. Richardo and Wade (2001) suggested that the success of most organizations depends on high return on equity and this could be probably due to establishment of good employees' performance management system. Garg (2007) however, noted that firm performance could be measured by return on asset and ratio of sales to assets. Profitability ratios designate a company's overall efficiency and performance (Hossan \& Habib, 2010) and it measures how the company uses its assets and control of its expenses to generate an acceptable rate of return to attract investors (Thachappilly, 2009).

\section{Firm Performance Importance}

For any firm, performance measurement is very critical for effective management (Demirbag, Tatoglu, Tekinus \& Zaim, 2006). Improvement of processes in a firm for good performance is not possible without measuring the outcomes. Hence, organizational performance improvement will require that some measurements be taken to find out the level to which the use of organizational resources impact business performance (Madu et al., 1996).

The firm's success over a certain period of time is normally explained by its performance and this is very crucial. Finding a measurement for the performance of the firm enables the comparison of performances over different time periods though there might not exist, any specific measurement that has the ability to measure every performance aspect (Snow \& Hrebiniak, 1980). Performance of a firm is impacted significantly by corporate governance and if the functions are well established it attracts investment and helps maximize the company's funds, reinforcing the company's pillars and this will result in the expected increase in firm performance. This implies that, effective corporate governance protects against probable financial challenges and facilitates remarkable growth and therefore, corporate governance plays a key role in the growth of the firm performance (Ehikioya, 2009).

\section{Financial Ratios}

Financial ratios are techniques used to examine the relative efficacy of entities by undertaking computations using financial statements. Financial ratios are used for different purposes including the ability of an entity to pay its debt and assessing the value of the entity (Barnes, 1987). Financial ratios are a preferred means of assessment because they could be adjusted to enhance comparison among firms (Barnes, 1987). Financial ratios are broadly used mainly to compute the profitability and financial state of a bank or firm. The firm stakeholders may include the owners, management, employees, customers, suppliers, competitors and academics, each having their views in applying financial statement analysis in their evaluations. 
The financial performance of entities can be measured by employing different ratios. These may include Return on Assets (ROA), Return on Equity (ROE), Profit Expense Ratio (PER), Return On Deposit (ROD), Net Interest Margin (NIM), Loan to Deposit ratio (LDR), Cash To Deposit Ratio (CDR), Debt to Equity Ratio (DER), Loan to Assets Ratio (LAR), Equity Multiplier (EM) Debt to Total Asset Ratio (DTAR), Asset Utilization (AU), Non- performing Loans to Total Loans, Income to Expense ratio (IER) and Operating Efficiency (OE) (Dufera, 2010). However, the most common measures that several Fls use to assess performance are return on total assets (ROA) and return on total equity (ROE) (Al-Matari, Al-Swidi \& Fadzil, 2014; Al-Qudah, 2015; Favero et al., 2006; Haniffa \& Hudaib, 2006). Analysts have used these measures in assessing the performance of various entities in terms of forecasting trends and predicting corporate failure (Gilbert \& Wheelock, 2007). Also, ROA, as an accounting-based measurement, gauges the operating and financial performance of the firm (Klapper \& Love, 2002). The measurement is such that the higher the ROA, the effective is the use of assets to the advantage of shareholders (Haniffa \& Huduib, 2006). Higher ROA also reflects the company's effective use of its assets in serving the economic interests of its shareholders (Haslindar \& Abdul Samad, 2011). When the relationship between corporate governance and firm performance is bing investigated, accounting-based performance measures which presents the management actions outcome are preferred over market-based measures (Hutchinson \& Gul, 2004; Mashayekhi \& Bazazb, 2008). As a result, a company showing a positive performance through ROA indicates its achievement of prior planned high performance (Nuryanah \& Islam, 2011). Negative profitabilities could be obtained and this could lead to negative ROAs (Kumi, Amoamah \& Winful, 2013). A negative performance indicates failure of the planned high performance which requires revision of plans to enhance short-term performance. Such negative performance means a great loss to both local and foreign investors. Thus if such companies want to be competitive in the open market then they have to update their objectives from time to time to ensure their goals for profitability are being met (Nuryanah \& Islam, 2011).

Ngutor et al (2013) indicated that it is relevant to take into account the ROE in relation to ROA to determine if the $\mathrm{FI}$ is attaining a profitable return on their borrowed funds. The ROA measures the return on all $\mathrm{FI}$ assets and is frequently utilized as a general index of profitability, and the higher the value, the more profitable the FI. The ROE measures the rate of return on the shareholder's equity employed in the Fl. It is an indicator of how well the $\mathrm{Fl}$ is managing its available resources and assets to net higher profits. Return on Asset (ROA) and Return on Equity (ROE) are used as indicators of the financial performance of banking because the return on assets is used to measure the effectiveness of companies in generating a profit by utilizing own assets. If the Return on Asset increases, the profitability of the company increases. It affects the increase in profitability gained by shareholders. One of the key reasons why Fls operate is to make a profit to reward its shareholders; hence, ROE is an indicator that proves to shareholders, as well as other stakeholders, the earnings which they made from the money invested by the investors (Ahsan, 2012).

Companies, financial institutions etc. normally use this profitability ratio to show their ability to financially perform well and generate profit. Therefore regular determination of this ratio is very important for company shareholders (Ahsan, 2012). For example, ROE was mentioned 32 times by Warren Buffet who encouraged the use of ROE for over 20 years in his annual letters to shareholders (Price, 2012). Company characteristics can be categorized into two groups ratios including return on assets, return on sales and current ratio and capital structure ratios namely total debt, long-term debt and short-term debt ratios and these could be 
related to ROE (Berzkalne - Elvira Zelgalve, 2014). However, in some organizations ROEs may not be related to company characteristics per se but value could be influenced by government policies such as subsidies. For example, Berzkalne - Elvira Zelgalve (2014) examined 450 companies over the between 2004 and 2012 and realized that agriculture companies did not show volatile ROEs in during the study period and this ratio still remained above $10 \%$ and during recession due to government policies and subsidies. Thus, in this study ROE of agriculture companies was not generally correlated and associated with other company characteristics. Using food production companies as example it was found out that during recessions a lot of profitable companies had less debts irrespective of maturity. In the case of retail companies the study revealed that higher ROEs are associated with bigger companies though their asset structure and long-term debt ratio were negatively correlated with ROE. The dynamics of ROE can be classified as pre-crisis and economic recession and recovery periods (Berzkalne - Elvira Zelgalve, 2014). ROE was significantly higher in retail and food production companies in the first period, while ROE of agriculture companies was still positive. However, during the recession period and recent years - profitability for both food production and retail industries were negative meanwhile, agriculture companies maintained slightly above $10 \%$ ROE. It could be explained that agriculture companies had a steady ROE, with no negatives during the recession due to the small equity capital that is, a small denominator with a minor increase in the numerator can result in a high ratio and high profitability in the agricultural companies could be attributed to government subsidies of which the other companies did not have (Berzkalne - Elvira Zelgalve, 2014). In other studies, Kumi et al. (2013); Bank of Ghana (2010) and Ibendahl (2018) indicated ROEs of $18-45 \%$ and up to $83.32 \%$ by Sika-Dapaah (2016). However, in the UK and US most companies have ROEs between 10-12\% (Sherman, F. 2018).

\section{Importance of Financial Ratios}

Financial ratios are very useful in financial analysis. The following, according to Lermack (2003), are some of the benefits that financial ratios possess; a) They are used to measure performance and set performance standards. b) They allow parties outside the organization to assess the creditworthiness of the organization. c) They allow firms to know their strengths and weaknesses and help these firms to focus on improving these identified weaknesses.

\section{Advantages of Financial Ratios}

Financial Ratio Analysis (FRA) has many advantages including its ability and effectiveness in differentiating high performance banks from others and compensating for disparities and controls for any size effect on the financial variables being studied (Samad, 2004). In addition, a bank's specific strengths and weaknesses can be identified using FRs and these ratios can provide information about bank profitability, liquidity and credit quality policies (Hempel, Simonson \& Coleman, 1994). The past performance of banks could be evaluated by the use of FRA and such analysis could indicate the history of the banks' financial performance in terms of earnings or risks for proper future planning (Hempel et al., 1994).

\section{Limitations of Financial Ratios}

Lermack (2003) in his work identified some limitations associated with using financial ratios as a tool for performance analysis. i) There is no acceptable law or rule as to what the right number of ratios is. ii) The accuracy of comparability among firms using ratios is low as firms may be using different accounting practices. lii) Ratios may only provide indications of the 
past since they are applied on the financial statements which are prepared on historical accounting records. iv) Arslan and Ergec (2010), as cited in Oztorul (2011), argued that the sheer number of ratios cause discouraging and not consistent results making them unsuitable for measuring the overall performance of organizations despite the fact that each ratio relates to a specific aspect of activities of these organizations. v) Ratios are also criticized for showing just the level of efficiency and not being able to detect the sources of inefficiencies (Daley \& Matthews, 2009 as cited in Oztorul, 2011).

\section{Empirical Review}

This section provides an empirical review of studies carried out on Return on Assets and Return on Equity as a measure of financial performance in financial institutions and their relationships.

\section{Review of Return on Assets (ROA)}

Return on Assets (ROA) is amongst financial ratios that have been widely used by most firms as a short term performance pointer in risk management (Al-Matari et al., 2014). Kenny, Jumoko and Faderera, (2014) indicated that ROA can assist investors know how much earnings have been generated by funds that have been invested in capital assets and how efficiently these earnings have been utilized under good management for profits (Al-Matari et al., 2014). ROA is an indicator that evaluates the efficient use of assets to obtain profits to investors that is, the earnings that have been generated by funds that have been invested in capital assets. In other words, the efficient use of a company's assets is best depicted by the return rate on its assets (Kenny et al., 2014).

Because Management of Fls including banks is accountable for their operations and utilization of the bank's assets, ROA could be an indicator that allows investors to know how well the Fls risk management practices are functioning so far as improving the level to which the bank's management is running efficiently is concerned (Kenny et al., 2014). Knowledge of the ROA of a company can be useful in comparing a company's profitability over multiple a period of time and comparisons could be made with similar companies in terms of size and industry. Banks for example may have a large number of total assets on their books in the form of loans, cash, and investments. When a bank is large, it could easily have over $\$ 2$ trillion in assets while putting up a net income that's similar to companies in other industries. The bank's ROA will be lower though the bank's net income or profit might be similar to an unrelated company and the bank might have high-quality assets. The larger number of total assets is normally divided into the net income, creating a lower ROA for the bank. Auto manufacturing companies for example may require huge facilities and specialized equipment. A software company that trade in downloadable programs online may generate the same net profits, but it could have a significantly higher ROA than its counterparts dealing with more heavy assets. When using this ratio to compare productivity across businesses, it's account must be taken of what types of assets are required to function in any given industry, rather than just comparing the figures (Boyte-White, 2020).

The ROA ratios will vary widely across different industries. Return on assets show the capital intensity of the company and this is dependent on the type of industry. For example, some companies will require large initial investments and this will generally yield lower return on assets even if they are doing well. ROAs over $5 \%$ are generally considered good (Ibendahl, 2018). ROAs could be compared with other financial ratios to give you a better idea of how well it's doing rather than just considering its ROA alone. When a company has a low 
percentage ROA, it means that the company is not making enough profits from its assets usage. For example if a company has machinery which is low in production efficiency, this will lead to a lower production and the cost of production will not positively yield profits (BoyteWhite, 2020). It's been argued that most companies in the beginning of their operations may have low ROAs due to high investment of say expensive machinery and this may be acceptable but if this situation persists over the years, then caution must be taken. This condition normally arises if the return on such assets is low for the initial years and for that matter may not be wise for management to make such investments (Dummies, 2011).

Low ROAs especially lower than the industry average implies inefficient use of company facilities, machinery or fleet. Facilities may be too large for the company, the company may have many fleet vehicles parked instead of hauling manufactured goods or outdated with high maintenance cost and machinery may be operating below capacity. In addition, Long-term or capital leases may cost more per square foot than the yields in sales per square foot by the company (Dummies, 2011). A consistently low ROA by a company is a clear indication of poor strategic management. In practice such companies may be expanding too quickly by purchasing several plots of land, buildings and equipment leading to sharp increase in its assets and capital expenditures. If actual sales and income do not meet management's growth projections, then this might backfire (Dummies, 2011). Poor use of company's assets including production facilities and share of responsibilities could also affect profitability and lead to low ROAs. In such situations some of the functions could be consolidated (Dummies, 2011).

When ROAs are being compared, it is better to compare firms in the same industry or similar businesses and their respective assets required to ascertain whether the ROA is good or bad. For example, high investment in assets may be associated with trucking companies because they require fleets of large trucks and this will lead to low ROAs by such companies. On the other hand, a Software firm that trade in download programmes or an advertising agency will require less amount of fixed assets and their ROAs will be much higher. However, a company with an extraordinarily high ROA could also mean a bad signal. For example if that company's equipment are running down and they are not investing in new ones ROA will increase in the short term but this will reduce in the long-term as productivity of its equipment declines. Generally, firms with high amounts of assets have ROAs less than 5 percent. Conversely, firms with ROAs more than 20 percent may need lower levels of assets to fund their operations. ROA is a very important analytical tool for business managers and investors. To achieve a reasonable ROA is an essential management practice for running companies and these must be monitored over the years to study trends and performance related to other businesses in similar industries.

ROA values could be negative (-0.08 and -0.22$)$ as observed by Sika-Dapaah (2016). This could happen if for example a company lost money or gained assets in excess of their profits, this will be a negative percentage or that company purchased a large piece of equipment such that net profits are negative it will result in a negative ROA (Marzec, 2017). When ROA is negative, it may indicate that the company trended toward having more invested capital or earning lower profits (Marzec, 2017).

\section{Review of Return on Equity (ROE)}

Return on Equity (ROE) is a profitability ratio which shows how well the $\mathrm{FI}$ can use equity investments to earn profits for shareholders (Al-Matari et al., 2014). ROE is associated with other major accounting-related indicators to measure a company's financial performance (Vanroose \& D'Espallier, 2013). Financial ratios were used to assess the financial performance 
of seven selected banks in Ghana from 2015 to 2018 and ROE values obtained were between $0.001 \%$ - 34\% (Agyeman, Bardai \& Ntoah-Boadi, 2020). The primary aim of every business enterprise is to make profits for the benefit of its shareholders and other investors. Hence, ROE is one of the indicators used to proof to shareholders and other stakeholders the earnings which they received from their investments (Vanroose \& D'Espallier, 2013). ROE may not be risk-sensitive (Al-Matari et al., 2014). For example, the amount of assets that are risky and the solvency event may not be captured in ROE figures and the long-term strategy or essential extra-ordinary components may not be considered. Hence, ROE may not be solely considered as an independent performance measure (Dummies, 2011).

Generally, a high return on equity is better than a low one. A high ROE proofs to shareholders that the cash infusions from equity invested in the company is being put to good use and yielding additional revenue. However, a low ROE at a point doesn't always mean poor performance of the company. For instance, a company may just receive a large amount of equity and use it to buy equipment to produce more products. Till the time that the equipment will be running at full capacity, return on equity will appear low. Thus, it is most often better to examine a variety of ratios over a stipulated long period to measure the company's performance. However, ROE values could be negative as observed by Sika-Dapaah (2016) who obtained ROEs of -0.083 and -0.183 in his study and this could be due to losses incurred by the Bank during those periods.

\section{Relationship between Return on Assets and Return on Equity}

Return on Assets is a financial ratio that measures a company's capability to earn profits as a result of utilization of total owned assets by the company. Higher ROA of a company performance will lead to a more effective company (Wild, Subramanyam \& Halsey, 2005) so that it can be seen as a positive sign for investors to invest their stock in the company. In other words, ROA affects the corporate value (Nofrita, 2013; Yulistiana, 2009; Yuniasih \& Wirakusuma, 2007). The mean of ROA percentage of registered manufacturing companies in ISE in the period of $2006-2010$ was $5.32 \%$. A good ROA normally depicts a better company management on the stock and this is reflected in the profits accrued. Return on Equity is used to measure the company capability to create profits on overall owned capital. It is calculated based on division of net profit after tax and total equity. The mean of ROE percentage of registered manufacturing companies in ISE in the period of $2006-2010$ was $10.93 \%$. This value indicates higher ROE by manufacturing companies compared to maximum banking deposit interest rate by $6.46 \%$. It means that practitioners can obtain more profit if they invest in manufacturing companies than if they save their funds in bank in the form of deposit saving (Rosikah et al., 2018).

ROA greater than $5 \%$ implying gaining 5 pesewas on every cedi spent on utilization of assets is considered good whilst ROE greater than $10 \%$ that is, 10 pesewas on every cedi invested as equity is also good (Ibendahl, 2018). However, in practice when comparing ROA to ROE, ROE should be greater than ROA but this at times may not happen in some farming businesses and may mean that a farm is earning less on its debt capital than its cost of borrowing that capital. It is never a good situation for a farm to borrow money at one rate of interest and then earn a rate of re- turn lower than that borrowing rate. For an odd year, a farm may find that ROA $>$ ROE because of lower yields or prices. If it happens only occasionally then this is usually not a problem. However, if a farm finds that ROA $>$ ROE consistently, then that farm needs to rethink how it is using debt capital. For a farm to succeed long term and use debt capital then ROE should be consistently greater than ROA. ROA can be greater than ROE due to 
unpredictable weather and prices in farm business (Ibendahl, 2018). In a company with no debt, ROE and ROA will be equal. But the more debt you have, the lower your return on assets will be because the denominator in the ROA calculation gets bigger. Therefore, a return on equity significantly larger than your return on assets could be a sign of too much debt.

\section{Methodology}

\section{Research Design}

This study used a quantitative research approach to calculate the ROA and ROE ratios for measuring the financial performance using secondary data obtained by the researcher.

\section{Sample Size and Sampling Technique}

Sample size taken was fifteen (15) Fls (Appendix I). The samples were selected using convenience sampling regarding Fls whose financial statements were easily available on-line from literature or from their website.

\section{Data Collection Procedures}

This section indicates how data was collected to answer the research questions and also provides the instrument as well as the sources from which these data were collected.

\section{Sources of Data}

The use of data is very imperative in order to succeed in research. The study employed secondary data sources from the financial institutions' (Appendix I) financial reports for 2018 and 2019.

\section{Data Collection Instrument}

The secondary data (Appendix II) was collected from literature (Ewool \& Quartey, 2021) and on-line annual reports from the selected banks (Annual report, 2018; Annual report, 2019). Variables of interest from the 2018 and 2019 reports that were extracted for the calculation of financial performance ratios (ROA) and (ROE) included Net income, Total Assets and Shareholder's Equity (Appendix II).

\section{Data Analysis}

Data were entered and ultimately analyzed using Micro soft office Excel 2007. The net income or profit and total assets for 2018 and 2019 were all entered in Excel and averages calculated. ROA and ROE ratios were then calculated and converted to percentages. Graphs were drawn using the ROA and ROE percentages against the Fls to compare graphically these two indicators and the financial performance of the Fls.

\section{Analysis for Return on Assets (ROA)}

The equation according to Harvard (n.d) is as follows:

$R O A=\frac{\text { Net Profit (present) }}{\text { Beginning Total Assets }+ \text { Ending Total Assets } / 2}$

Where ROA=Return on assets, which is the ratio of net Profit or income present to average total assets. A ratio of 0.05 to 0.20 representing $5 \%$ to $20 \%$ was generally accepted as a good financial performance in relation to usage of Assets and it shows how efficient the company is at generating profits (Birken \& Curry, 2021; Speights, 2021). However, ROE values for high profitability in terms of shareholders equity invested may be generally higher than ROA values (Furhmann, 2021). 


\section{Analysis for Return on Equity (ROE)}

The equation according to Harvard (n.d) is as follows:

$R O E=\frac{\text { Net Profit (present) }}{\text { Beginning Equity+Ending Ending } / 2}$

Where ROE=Return on Equity, which is the ratio of net Profit or income present to Average shareholders' Equity.

\section{Rankings for Fls based on ROA and ROE ratios}

Overall rankings of the $15 \mathrm{Fls}$ were done in the order of the highest ratio to the least to assess the financial performance of the Fls across all groups (Credit Union, Savings and Loans, Rural Banks and Commercial Banks) because they are all Fls. A second ranking similarly was done within each group to ascertain their performance within their peer groups (Boyte-White, 2020).

\section{Results and Discussion}

Financial Performance and Rankings of Financial Institutions

Results of financial performance ROA, ROE and the rankings of the Fls are presented in Table 1.

Table 1. Financial Performance and Rankings of Financial Institutions

\begin{tabular}{lcccccc}
\hline & & & \multicolumn{2}{c}{ Rankings (ROA) } & \multicolumn{2}{c}{ Rankings (ROE) } \\
Financial Institution & ROA (\%) & ROE (\%) & Same & Overall & Same & $\begin{array}{c}\text { Overal } \\
\text { group }\end{array}$ \\
& & & & 2 & 2 & 3 \\
\hline CU SRI & 5.4 & 59.1 & 2 & 2 & 1 & 2 \\
CU KsTU & 9.9 & 74.0 & 1 & 1 & 3 & 4 \\
CU K Anokye & 4.7 & 34.6 & 3 & 3 & 4 & 13 \\
CU Ramseyer & 0.7 & 5.2 & 4 & 13 & 1 & 7 \\
S\&L Sinapi & 1.8 & 26.7 & 1 & 11 & 2 & 12 \\
S\&L Opportunity & 0.8 & 5.5 & 2 & 12 & 4 & 14 \\
RB Bosomtwe & 0.2 & 1.9 & 4 & 14 & 1 & 1 \\
RB Otuasikan & 1.8 & 81.4 & 3 & 10 & 2 & 5 \\
RB Ahafo Ano & 3.0 & 33.1 & 1 & 8 & 3 & 8 \\
RB Mponua & 2.2 & 26.6 & 2 & 9 & 1 & 6 \\
CB Ghana Commercial & 3.5 & 27.3 & 4 & 7 & 4 & 11 \\
CB Access & 4.2 & 24.0 & 2 & 5 & 2 & 9 \\
CB Cal & 3.6 & 26.2 & 3 & 6 & 5 & 15 \\
CB Universal & -1.5 & -11.5 & 5 & 15 & 3 & 10 \\
CB UBA & 4.7 & 25.6 & 1 & 4 & 2 \\
\hline
\end{tabular}

ROA=Return on Assets; ROE=Return on Equity; $C U=C r e d i t$ Union; S\&L=Savings and Loans; $\mathrm{RB}=$ Rural Bank; $\mathrm{CB}=$ Commercial Bank;

The results showed that mean ROA of the Fls ranged from -0.015 (1.5\%) (Universal BankCommercial Bank) to 0.099 (9.9\%) (Kumasi Technical University - Credit Union). Three of the credit unions namely Kumasi Technical University, Soil Research Institute, Komfo Anokye Teaching Hospital and a commercial bank United Bank of Africa (UBA) had mean ROA ratios of 0.099 (9.9\%), $0.054(5.4 \%), 0.047(4.7 \%)$ and 0.047 (4.7\%) respectively. These values were 
$\geq 0.05(5.0 \%)$ which is an acceptable indicator of good financial performance by most firms (Birken \& Curry, 2021; Boyte-White, 2020; Ibendahl, 2018). This meant that these Fls were able to earn profits of $\geq 5$ pesewas per one cedi on the amount of total assets invested in their business and indicated that these firms efficiently employed their assets (Ngutor et al., 2013) and significantly gained some profits under good management in agreement with Al-Matari et al. (2014); Haniffa \& Huduib (2006); Haslindar \& Abdul Samad (2011) and Kenny et al. (2014). The Fls that had ROA ratios< 0.05 implied that these Fls were making less than 5 pesewas per one cedi invested in their assets and thus were not obtaining enough income. This meant that their production efficiency was low and could not make much profit in terms of usage of their assets (Boyte-White, 2020). The low percentages of ROAs obtained could be attributed to the fact that probably these Fls recently purchased assets of which they are not making enough income from the use of those assets especially for the first few years or inefficient use of these facilities. The implication is that if such low ROAs are continuously observed over the years then this may pose bad signals to investors and poor strategic management of the Fls could be blamed for this (Dummies, 2011). The negative ROA observed at Universal Bank could be attributed to the fact that the company gained assets in excess of their profits or they purchased assets such that their net profits were negative (Al-Matari et al., 2014; Kumi et al., 2013; Marzec, 2017). This implied that the company trended toward having more invested capital or earning lower profits (Marzec, 2017). The negative performance indicated failure of planned high performance and strategic management. This could discourage investors from investing in such Fls (Al-Matari et al., 2014).

Results from Table 1 also showed that mean ROE of the Fls ranged from -0.115 (11.5\%) (Universal Bank-Commercial Bank) to 0.814 (81.4\%) (Otuasikan Rural Bank). With the exception of four of the Fls namely Ramseyer credit union, Opportunity Savings and Loans, Bosomtwe Rural Bank and UBA which had ROEs of 0.052 (5.2\%), 0.055 (5.5\%), 0.019 (1.9\%) and $-0.115(11.5 \%)$ respectively, all the other Fls had ROE ratios $>20 \%$ which is an acceptable indicator of good financial performance by most firms (Agyeman et al., 2020; Birken \& Curry, 2021; Boyte-White, 2020; Ibendahl, 2018). This meant that these Fls were able to earn profits of $>20$ pesewas per one cedi on the amount of total assets invested in their business and indicated that these firms earned profits with respect to the amount of equity put in the business and this was in agreement with observations from Kumi et al., (2013); Bank of Ghana, (2010) and Ibendahl, (2018) who indicated ROEs of $18-45 \%$ and up to $83.32 \%$ by Sika-Dapaah (2016). The implication is that it proves to shareholders, as well as other stakeholders, the earnings which they made from the money invested by the investors (Al-Matari et al., 2014). This indicates to shareholders that the company is putting cash infusions from equity to good use and earning additional revenue and that the business is doing well as they are able to generate a high amount of profit, given a particular level of investments in the form of equity (Al-Matari et al., 2014). However, excessively high ROE values obtained from this study may not necessarily mean higher efficiency and profitability since liabilities like long term debts are subtracted from assets when shareholders equity is computed and this affects ROE values because higher debts will reduce the denominator in the ROE formula and lead to higher ROE as reported by Bromels (2020). The Fls that had ROE ratios< $0.10(10 \%)$ implied that these FIs were making less than 10 pesewas per one cedi equity invested indicating low incomes generated, low efficiency and poor management (Agyeman et al., 2020). The implication is that such low ROEs if continuously observed over the years may pose bad signals to shareholders and other investors (Dummies, 2011). The negative ROE observed at Universal Bank was in agreement with Sika-Dapaah (2016) who also observed negative ROEs in his 
study. The negative ROEs in this study could be attributed to the fact that the company earned lower and negative profits in 2019 (Al-Matari et al., 2014; Kumi et al., 2013; Sika-Dapaah, 2016). This implied that the company probably incurred some losses during that year and could not make profits. The negative performance indicated failure of planned high performance and strategic management. This could discourage shareholders and investors from investing in such Fls (Al-Matari et al., 2014).

Rankings using ROA (Table 1) within the financial institutions described as same group indicated that KsTU, ranked first (9.9\%) amongst the four Credit Unions studied. In the case of the Savings and Loans, Sinapi ranked first (1.8\%) amongst the two studied. Ahafo Ano Rural Bank ranked first (3\%) within the rural bank group of 4 while United Bank of Africa ranked first (4.7\%) amongst the commercial banks. Though these Fls ranked first, Sinapi Savings and Loans and Ahafo Ano Rural Bank could not meet the minimum ROA of $5 \%$ for good performance in terms of Asset usage (Birken \& Curry, 2021; Boyte-White, 2020; Ibendahl, 2018).

Rankings using ROE (Table 1) within the financial institutions described as same group indicated that KsTU again ranked first (74.0\%) amongst the four Credit Unions studied. In the case of the Savings and Loans, Sinapi Aba again ranked first (26.7\%) amongst the two studied. Otuasikan Rural Bank ranked first (81.4\%) within the rural bank group of 4 studied and Ghana Commercial Bank ranked first $(27.3 \%)$ amongst the commercial banks. Though KsTU and Otuasikan were amongst the first ranked within their group, they had excessively higher ROEs which might indicate huge debts which when subtracted from the total assets for the computation of ROE may reduce the denominator leading to high ROEs (Bromels, 2020). These ROE values were far higher in contrast to $10-12 \%$ reported in most firms in the UK and USA (Sherman, 2018).

\section{Comparison between ROA and ROE as Financial Performance Indicators of Fls}

The comparison between ROA and ROE ratios as financial performance indicators of the Fls is presented in Figure 1. It was observed from the figure that the ratios of ROEs were greater than those of the ROAs. This is in agreement with Ibendahl (2018) depicting the norm though the reverse can happen in some farm business due to unpredictable weather and prices in farm business (Ibendahl, 2018). 


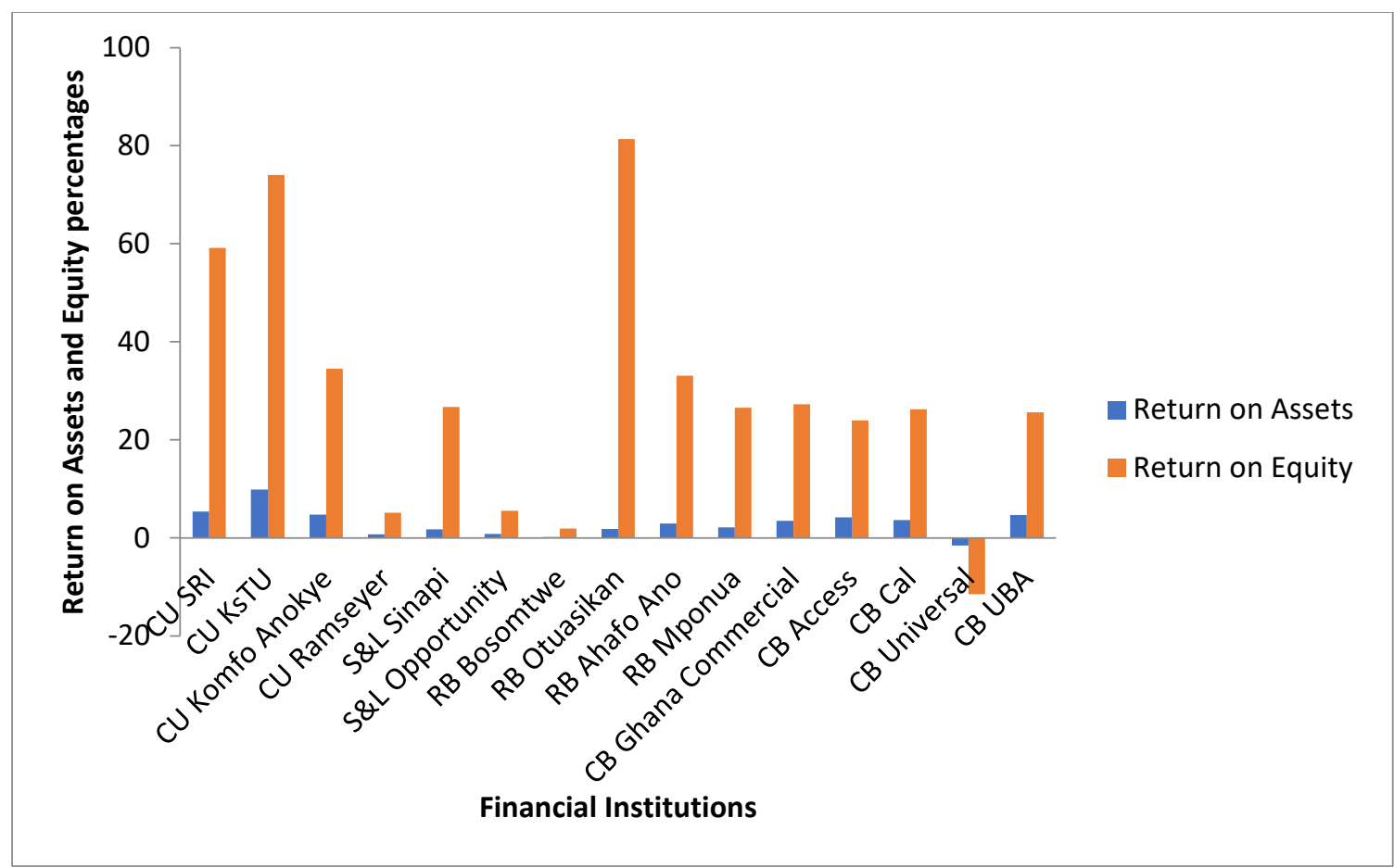

Figure 1. Comparison between ROA and ROE as Financial Performance Indicators of Financial Institutions

\section{Conclusions, Recommendations \& Suggestions for Future Research}

The study used two years financial data for computerization of the financial performance of the Fls. Since length of years could affect ROA and ROE values and also show trends, it is recommended that future studies could be done using 5-10 years financial statement data. The study recommends that, Fls that had low and negative ROAs and ROEs must look at how the Fls are being managed, the efficiency of such Fls and their income generation as against assets and liabilities acquired. The Fls must evaluate and update their objectives from time to time if it is desirous of competing in the market place. Conversely, Fls that had exceedingly higher ROEs must avoid liabilities like long term debts that could shoot up very high ROEs. It was observed from the studies that ranking orders may not necessarily imply good management and efficiency of the Fls and that assessment of individual Institutions especially within same group must be critically looked at to determine their own peculiarities. Within group assessment is highly recommended since the ratios will vary widely across different industries.

\section{Theoretical and Contextual Contribution of this Research to Existing Knowledge}

Several developing nations including Ghana are undergoing various financial system transformations and innovations over the past two decades. In Ghana for example, 319 microfinance institutions are operating out of 683 registered beside 28 commercial banks that are in compliance with BoG standards. The closure of most of these MFIs and merging of some of the commercial banks were as a result of poor management coupled with weak internal and external control systems and increased risks (Addo, 2014; Appiah-Konadu, Churchill, Agbodohu, \& Frimpong, 2016; BoG, 2018). Studies assessing the financial performance of banks have received less attention (Adam, 2014). Therefore, this study included selected banks to fill this gap and contribute to literature. Due to the current BoG reforms (BoG, 2018) there is the need for a constant tracking of the financial performance of the various Fls in 
Ghana to prevent possible collapse. Information from this study will help guide management in its strategic plans to enhance efficiency and profitability of these Fls. Therefore, this study to assess the financial performance of some financial institutions in Ghana to obtain information for the various stakeholders in these selected Fls to help them in their decision making and policies. A constant assessment of the financial performance has become necessary in view of the BoG financial sector reforms which non-performing institutions may be closed down or merged.

\section{Limitations of the Study}

The study was limited to the number of Fls whose publications of financial statements were easily accessed on-line through Literature or on their website. The availability of time for this study was limited and could not permit the consideration of all the Fls in Ghana.

\section{Acknowledgments}

We wish to express our sincere thanks to the Head of Department Dr. Francis K. Bonbinuba and entire staff of the Department of Accountancy and Accounting Information Systems and all others who supported us in this study. We are grateful to Dr. Manfred B. Ewool formerly of CSIR-Crops Research Institute and Mrs. Felicia Ewool for their financial support in the conduct of this study.

\section{References}

Adam, M. H. M. (2014). Evaluating the Financial Performance of Banks using Financial RatiosA Case Study of Erbil Bank for Investment and Finance. European Journal of Accounting Auditing and Finance Research, 2(6), 162-177.

Addo, C. K. (2014). Overtrading Versus Lack of Qualified Staff as Cause of Failure of Microfinance Institutions in Ghana: A Conceptual Investigation. Research Journal of Finance, 2(11).

Agyemang, J. K. Bardai, B. B., \& Ntoah-Boadi, S. (2020). Empirical Analysis of the Financial Performance of Listed Banks in Ghana. International Journal of Accounting and Financial Reporting. 10(1) ISSN 2162-3082.

Al-Matari, E., Al-Swidi, A., \& Fadzil, F. (2014). The Measurements of Firm Performance's Dimensions. Asian Journal of Finance and Accounting, 6(1), 24-49.

Al-Qudah, Al-Afeef. (2015). The Relationship between the Investment in Current Assets and Profitability \& Liquidity. Journal of Finance and Investment Analysis, 4(4), 11-22

Annual report. (2018). Retrieved from https://www.gcbbank.com.gh; https://www.ghana.accessbankplc.com; https://calbank.net; https://www.myumbbank.com; https://www.ubaghana.com.

Annual report. (2019). Retrieved from https://www.gcbbank.com.gh; https://www.ghana.accessbankplc.com; https://calbank.net; https://www.myumbbank.com; https://www.ubaghana.com.

Appiah-Konadu, P., Churchill, F. Q., Agbodohu, W., \& Frimpong, H. K. (2016). Evaluating the Credit Risk Management Practices of Microfinance Institutions in Ghana: Evidence from Capital Line Investment Ltd. and Dream Finance Ltd. Archives of Business Research, 4(5), 72-80.

Bank-news (n.d). Retrieved from http://en.wikipedia.org/wiki /Bank

Bank of Ghana. (2010): Annual Report-2009, High Street, Accra (www.bog.gh). 
Bank of Ghana. (2011). Operating Rules and Guidelines for Microfinance Institutions. Notice to Banks, Non-Bank Financial Institutions and The General Public. Notice No. BG/GOV/SEC/2011/04.

Bank of Ghana. (2018). Notice on Licensed Microfinance Institutions. No. BG/GOV/SEC/2018/05.

Barnes, P. (1987). Analysis and Use of Financial Ratios: A Review Article. Journal of Business Finance and Accounting, 14(4), 589-609.

Benton, E. G., \& James, W. K. (2005), “Commercial Banking”, 3rd Edition, Text, the management of risk, John wiley and sons.

Berzkalne - Elvira Zelgalve, I. (2014). Equity and Company Characteristics: An Empirical Study of Industries in Latvia. The 8th International Day of Statistics and Economics, Prague, September 11-13, 2014. 10pgs

Birken, E. G., \& Curry, B. (2021). Return on Assets (ROA) definition. Retrieved from https://www.forbes.com>advisor>investing $>$ ROA-return

Bititci, U., Carrie, A., \& McDevitt, L. (1997). Integrated performance measurement systems: A development guide. International Journal of Operations \& Production Management, 17(5), 522-534.

Boateng, A. A., \& Boateng, G. O. (2014). An Appraisal of Risk Management Practices of Microfinance Institutions in Ghana. Journal of Economics and Sustainable Development, 5(6), 14-18.

Boateng, G. O., Boateng, A. A., \& Bampoe, H. S. (2015). Microfinance and Poverty Reduction in Ghana: Evidence from Policy Beneficiaries. Review of Business \& Finance Studies, 6(1), 99-108.

Boateng, I. A., \& Agyei, A. (2013). Microfinance in Ghana: Development, Success Factors and Challenges. International Journal of Academic Research in Accounting, Finance and Management Sciences, 3(4), 153-160.

Boyte-White, C. (2020). How to calculate Return on Asset (ROA) with examples. Retrieved from https://www.investopedia.com>Financial Ratios

Bragg, S. M. (2012). Financial analysis: A controller"s guide (2nd Edition), John Wiley \& Sons, inc, Hoboken, New Jersey

Bromels, J. (2020). Return on Equity: What is it and why does it matter? Retrieved from https://www.fool.com/investing/how-to-invest/stocks/return-on-assets

Cascio, W. F. (2006). Managing Human Resources: Productivity, Quality of Life, Profits. McGraw-Hill Irwin.

Chenhall, R. H. (2005). Integrative Strategic Performance Measurement System, Strategic Alignment of Manufacturing, Learning and Strategic outcomes: an exploratory study.

Demirbag, M., Tatoglu, E., Tekinus, M., \& Zaim, S. (2006). An analysis of the relationship between TQM implementation and organizational performance: evidence from Turkish SMEs. Journal of Manufacturing Technology Management, 17(6), 829-847.

Dufera, A. (2010). Financial Performance Evaluation (A Case Study of Awash International Bank (AIB). A Research project submitted to the Department of Accounting and Finance, College of Business and Economics, Mekelle University, for the partial Fulfillment of the Degree of Master of Science in Finance and Investment

Dummies. (2011). Return on Assets (ROA) Ratio and Financial Leverage Gain; John A. Tracy. Retrieved from Return on assets - Wikipedia. https://en.wikipedia.org > wiki > Return_on_assets 
Ehikioya, B. (2009). Corporate governance structure and firm performance in developing economies: evidence from Nigeria. Q Emerald Group Publishing Limited, 9(3), 231243. http://dx.doi.org/10.1108/14720700910964307.

Ewool, L. M., \& Quartey, J. A. (2021). Evaluation of the Effect of Risk Management Practices on the Performance of Microfinance Institutions. International Journal of Academic Research in Accounting Finance and Management Sciences, 11(1), 211-240.

Favero, C. A., Giglio, S. W., Honorati, M., \& Panunzi, F. (2006). The Performance of Italian Family Firms. ECGI Working Paper No. 127/2006, http://ssrc.com/abstract_id=918181.

Furhmann, R. (2021). Return on Equity (ROE) vrs Return on Assets (ROA):What is the difference? Retrieved from https://www.investopedia.com $>$ Financial ratios

Garg, A. K. (2007). "Influence of Board Size and Independence on Firm Performance: A Study of Indian Companies", VIKALPA, 32 (3) $39-60$.

Gilbert, R. A., \& Wheelock, D. C. (2007). Measuring commercial bank profitability: proceed with caution. Networks Financial Institute Working Paper (p. 22), 2007-WP

Haniffa, R., \& Hudaib, M. (2006). Corporate Governance Structure and Performance of Malaysian Listed Companies. Journal of Business Finance and Accounting, 33 (7-8), 1034-1062

Harvard (n.d). Harvard Business School. A Manager's guide to Finance and Accounting Retrieved from https://info.online.hbs.edu>finance-accounting-ebook

Haslindar, I., \& AbdulSamad, F. A. (2011). Corporate governance mechanisms and performance of public-listed family-ownership in Malaysia. International Journal of Economics and Finance, 3(1), 105-115.

Hayes, A. (2021). What is Financial Institution (FI)? Retrieved from https://www.investopedia.com>Personal Finance $>$ Banking

Hempel, G., Simonson, D., \& Coleman, A. (1994). Bank management: Text and cases. (4th Edition), John Wiley \& Sons, Inc.

Horton, M. (2021). What are the 9 Major Types of Financial Institutions? Retrieved from https://www.investopedia.com>Personal Finance>Banking

Hossan, F., \& Habib, A. (2010), "Performance evaluation and ratio analysis of Pharmaceutical Company in Bangladesh", Master's thesis (Unpublished), University West, Bangladesh.

Hutchinson, M., \& Gull, F. (2004). Investment opportunity set, corporate governance practices, and firm performance. Journal of Corporate Finance, 10(1), 595-614.

Ibendahl , G. (2018). Comparing the Financial Ratios ROA and ROE. Kansas State University Department of Agricultural Economics - April 2018. http://www.agmanager.info

Kenny, A. S., Jumoke, O. O., \& Faderera, O. A. (2014). Risk Management Practices and Financial Performance: Evidence from the Nigeria Deposit Money Banks (DMBs). The Business and Management review, 4(4), 31-39.

Klapper, L., \& Love, I. (2002). Corporate governance, investor protection, and performance in emerging markets. Washington, DC. United States: World Bank. Mimeographed document.

Koufopoulos, D., Zoumbos, V., Argyropoulou, M., \& Motwani, J. (2008). Top management team and corporate performance: a study of Greek firms. Team Performance Management, 14(8), 340-363. http://dx.doi.org/10.1108/13527590810912322

Kumi, P. K., Amoamah, M. O., \& Winful, E. (2013). Evaluation of the Performance of Banks in Ghana Using Financial Ratios: A Case Study of Barclays Bank Ghana Limited (BBGL), Ghana Commercial Bank (GCB) and Agricultural Development Bank (ADB). Journal of 
Business and Management ISSN 2222-1905 (Paper) ISSN 2222-2839, 5(28) www.iiste.org.

Lebas, M. (1995). Performance measurement and performance management, International Journal of Production Economics, 41(1-3), 23-35.

Lermack, H. (2003). Steps to a basic company analysis. Philadephia, USA: Philadephia University.

Levine, R. (2003). Finance and Growth: Theory and Evidence. https://www.researchgate.net/publication

List of banks in Ghana (n.d). Retrieved from https://beraportal.com>list of banks in Ghana

Madu, C., Aheto, J., Kuei, C., \& Winokur, D. (1996). Adoption of strategic total quality management philosophies Multi-criteria decision analysis model. International Journal of Quality and Reliability Management, 13(3), 57 - 72.

Ahsan, M. A. F. M. (2012). "Can ROE be used to predict portfolio performance?" Economics, Management, and Financial Markets. 7.2. p132.

Marzec, E. (2017). What does it mean when a Return on Asset Ratio Decreases? Retrieved from https://www.bizfluent.com>Accounting

Mashayekhi, B. \& Bazazb, M. S. (2008). Corporate governance and firm performance in Iran, 4(2), 156-172. http://dx.doi.org/10.1016/S1815-5669(10)70033-3

Neely, A., Gregory, M., \& Platts, K. (2005). Performance measurement system design: A literature review and research agenda. International Journal of Operations \& Production Management, 25(12), 1128-1263.

Ngutor, N., Falaye, A. A., Onah, E., Nyor, A., Evans O. P., Abass, O., \& Adama, N.V. (2013). Analysis and Computation of the Performance of Microfinance Banks in Nigeria: A case study of Standard Microfinance Bank Yola. Progress in Applied Mathematics, 5(1), 6478.

Nofrita. (2013). Effects of Profitability on Corporate Value With Dividend Policy as Intervening Variable (Empirical Study in Manufacturing Companies Registered in BEI), State University of Padang.

Nuryanah, S., \& Islam, S. M. N. (2011). Corporate governance and performance: Evidence from an Emerging Market. Malaysian Accounting Review, 10(1), 17-42.

Oztorul, G. (2011). Performance Evaluation of Banks and Banking Groups: Turkey case. (Unpublished master's thesis). Middle East Technical University, Ankara, Turkey.

Price, J. (2012). Return on Equity Traps (and how to avoid them). Australian Shareholders' Association. Sogorb-Mira,

Ricardo, R., \& Wade, D. (2001). Corporate Performance Management: How to Build a Better Organization through Measurement Driven Strategies Alignment. Butterworth Heinemann.

Rosikah, Prananingrum, D. K., Muthalib, D. A., Azis, M. I., \& Rohansyah, M. (2018). The International Journal of Engineering and Science (IJES) 7(3 ver. I), 06-14. ISSN (e): $2319-1813$ ISSN (p): 23-19- 1805

Rouf, M. A. (2011). The relationship between corporate governance and value of the firm in developing countries: Evidence from Bangladesh. The International Journal of Applied Economics and Finance, 5(3), 237-244.

Samad, A. (2004). Bahrain commercial bank's performance during 1994- 2001. Credit and Financial Management Review 10(1) 33-40.

Sherman, F. (2018). Factors that Contribute to Change in Return on Equity. Retrieved from https://www.bizfluent.com>Accounting 
Sika-Dapaah, K. A. (2016). Comparative Analysis of Financial Performance of the three State Owned Banks in Ghana. Dissertation Submitted to Kwame Nkrumah University of Science and Technology, College of Humanities and Social Sciences, Department of Economics, In Partial Fulfillment of the Requirement for the Award of Master of Science in Economics

Snow, C., \& Hrebiniak, L. (1980). Strategy, distinctive competence, and organizational performance. Administrative Science Quarterly, 25(2), 317-336.

Speights. (2021). How to calculate Return on Assets (ROA). Retrieved from https://www.fool.com/investing/how-to-invest/stocks/return-on-assets

Stannack, P. (1996). Perspective on Employees Performance. Management Research News, Vol. 119 No. 4/5, 38-40.

Thachappilly, G. (2009). "Profitability Ratios Measure Margins and Returns: Profit Ratios Work with Gross, Operating, Pretax and Net Profits". Journal of profitability ratio measure margin and return In: Hossan, F. and Habib A. (Edition), "Performance evaluation and ratio analysis of Pharmaceutical Company in Bangladesh" Master's thesis (Unpublished), University West, Bangladesh

Vanroose, A., \& D'Espallier, B. (2013). Do Microfinance Institutions Accomplish Their Mission? Evidence from the Relationship Between Traditional Financial Sector Development and Microfinance Institutions' Outreach and Performance. Applied Economics, 45, 1965- 1982.

Wild, Subramanyam, \& Halsey. (2005). Financial Report Analysis. Eight Edition. Translated by: Yanivi S. Bachtiar and S. Nurwahyu Harahap. Salemba Empat. Jakarta.

Yulistiana. (2009). Effects of Earning Per Share (EPS), Return on Asset (ROA), and Operational Cash Flow on Corporate Value in Companies Registered in Jakarta Islamic Index 2004 - 2006. State Islamic University of Sunan Kalijaga.

Yuniasih, N. W., \& Wirakusuma, M. G. (2007). "Effects of Financial Performance on Corporate Value By Expressing Corporate Social Responsibility and Good Corporate Governance as Mediated Variables". Accounting Journal and AUDI Business Media. 4(1), 1-10. 


\section{APPENDICES}

\section{Appendix I: List of selected Financial Institutions}

List of Selected Financial Institutions in Ghana

\begin{tabular}{lll}
\hline No & Microfinance Institutions & Location \\
\hline $\mathbf{1}$ & Credit Union Soils Research Institute & Kwadaso-Agric \\
$\mathbf{2}$ & Credit Union Kumasi Technical University & Asafo \\
$\mathbf{3}$ & Credit Union Komfo Anokye & Bantama \\
$\mathbf{4}$ & Credit Union Ramseyer Presby & Adum \\
$\mathbf{5}$ & Savings and Loans Sinapi Aba & Ahodwo \\
$\mathbf{6}$ & Savings and Loans Opportunity International & Kejetia \\
$\mathbf{7}$ & Bosomtwe Rural Bank & Edwenase \\
$\mathbf{8}$ & Otuasikan Rural Bank & Kejetia \\
$\mathbf{9}$ & Ahafo-Ano Rural Bank & Suame \\
$\mathbf{1 0}$ & Atwima Mponua Rural Bank & Bantama \\
$\mathbf{1 1}$ & Ghana Commercial Bank & Ghana* \\
$\mathbf{1 2}$ & Access Bank & Ghana* \\
$\mathbf{1 3}$ & Cal bank & Ghana* \\
$\mathbf{1 4}$ & Universal Merchant Bank & Ghana* \\
$\mathbf{1 5}$ & United Bank for Africa & Ghana* \\
\hline & TOTAL & $\mathbf{1 5}$ \\
\hline
\end{tabular}

*Across Branches in Ghana 
INTERNATIONAL JOURNAL OF ACADEMIC RESEARCH IN BUSINESS AND SOCIAL SCIENCES

Vol. 11, No. 7, 2021, E-ISSN: 2222-6990 @ 2021 HRMARS

Appendix II. Financial Performance Data of Selected Financial Institutions in Ghana

Net income

$\underline{\text { Total assets }}$

\begin{tabular}{lllllll}
2018 & 2019 & Average & 2018 & 2019 & Average & A \\
\hline $356,735$. & $425,825.6$ & $391,280.6$ & $7,735,445.1$ & $8,020,527.8$ & $7,877,986.5$ & 0.0 \\
78 & 0 & 9 & 7 & 5 & 1 & 54 \\
$835,161$. & $974,600.3$ & $904,880.7$ & $9,300,812.0$ & $10,415,058$. & $9,857,935.4$ & 0.0
\end{tabular}

\begin{tabular}{|c|c|c|c|c|c|c|c|}
\hline \multirow[t]{2}{*}{ CU SRI } & 78 & 0 & 9 & 7 & 5 & 1 & 54 \\
\hline & $835,161$. & $974,600.3$ & $904,880.7$ & $9,300,812.0$ & $10,415,058$ & $9,857,935.4$ & 0.0 \\
\hline \multirow[t]{2}{*}{ CU KsTU } & 07 & 9 & 3 & 8 & 73 & 1 & 99 \\
\hline & $1,160,68$ & $546,299.0$ & $53,492.5$ & $10,688,431$ & $12,447,071$ & $11,567,751$. & .0 \\
\hline CU KATH & 6.06 & 8 & 7 & 96 & 69 & 83 & 7 \\
\hline $\mathrm{CU}$ & $339,287$. & $102,363.5$ & $220,825.7$ & $13,779,195$ & $15,370,130$ & $14,574,663$ & 0.0 \\
\hline \multirow[t]{2}{*}{ Ramseyer } & 89 & 7 & 3 & 98 & 35 & 17 & 07 \\
\hline & $905,339$. & $3,150,321$. & $2,027,830$ & $167,355,20$ & $183,768,80$ & $175,562,00$ & 0.0 \\
\hline S\&LSinapi & $\begin{array}{l}00 \\
-\end{array}$ & 00 & $\begin{array}{l}00 \\
-\end{array}$ & 7.00 & 5.00 & & 18 \\
\hline S\&LOppo & $6,382,41$ & $2,088,726$ & 842. & 236,9 & 261,5 & ,236,06 & 0.0 \\
\hline $\mathrm{rt}$ & 0.00 & 00 & 00 & 6.00 & 9.00 & & 08 \\
\hline \multirow{2}{*}{$\begin{array}{l}\text { RBBosom } \\
\text { twe }\end{array}$} & $1,308,88$ & & & & & & 0.0 \\
\hline & 1.00 & 0 & 0 & 00 & 00 & 00 & 02 \\
\hline \multirow{2}{*}{$\begin{array}{l}\text { RBOtuasi } \\
\text { kan }\end{array}$} & $1,002,57$ & $1,354,195$ & $1,178,383$ & & $79,964,358$ & $74,047,843$ & 0.0 \\
\hline & 2.00 & 00 & 50 & 00 & 00 & 50 & 18 \\
\hline \multirow{2}{*}{$\begin{array}{l}\text { RBAhafo } \\
\text { Ano }\end{array}$} & $631,151$. & $736,399.0$ & $683,775.0$ & & & 5,068 & 0.0 \\
\hline & 00 & 0 & 0 & 00 & 00 & 00 & 30 \\
\hline \multirow{2}{*}{$\begin{array}{l}\text { RBMpon } \\
\text { ua }\end{array}$} & $1,353,95$ & $1,267,600$. & $1,310,779$ & $56,134,360$ & $60,927,119$ & $58,530,739$ & 0.0 \\
\hline & 8.00 & 00 & 00 & 00 & 00 & 50 & 22 \\
\hline \multirow[t]{2}{*}{ CB GCB } & $\begin{array}{c}343,079 \\
00\end{array}$ & $\begin{array}{l}406,137.0 \\
0\end{array}$ & $\begin{array}{c}374,608.0 \\
0\end{array}$ & $\begin{array}{l}10,635,051 . \\
00\end{array}$ & $\begin{array}{l}12,416,741 . \\
00\end{array}$ & $\begin{array}{l}11,525,896 \\
00\end{array}$ & $\begin{array}{l}0.0 \\
35\end{array}$ \\
\hline & $38,680.0$ & 172 & $105,370.0$ & & & 319.5 & 0.0 \\
\hline \multirow[t]{2}{*}{ CB Access } & 0 & 0 & 0 & 0 & 0 & 0 & 42 \\
\hline & 152,185 & & $189,278.5$ & & $7,039,780.0$ & & 0.0 \\
\hline CB Cal & 00 & 0 & 0 & 0 & 0 & 0 & 36 \\
\hline \multirow{3}{*}{$\begin{array}{l}\mathrm{CB} \\
\text { Universal }\end{array}$} & $44,049.0$ & & & $2,523,526.0$ & $2,734,868.0$ & 2,629,197.0 & 0.0 \\
\hline & 0 & $-40,053.00$ & $1,998.00$ & 0 & 0 & 0 & 15 \\
\hline & 153,069 & $188,597,4$ & $170,833,5$ & $3,563,715,8$ & $4,497,680,3$ & $4,030,698,1$ & 0.0 \\
\hline B UBA & 753.0 & 25.00 & 89.00 & 70.00 & 51.00 & 10.50 & 47 \\
\hline
\end{tabular}

$\mathrm{CU}=$ Credit Union; $\mathrm{S} \& \mathrm{~L}=$ Savings and Loans; RB=Rural Bank; SRI=Soils Research InstituteKTU=Kumasi Technical University; KATH=Komfo Anokye Teaching Hospital; Opport=Opportunity International;KsTU=Kumasi Technical University 


\begin{tabular}{|c|c|c|c|c|c|c|c|}
\hline & $\frac{\text { Net }}{\text { income }}$ & & & Equity & & & \\
\hline & 2018 & 2019 & Average & 2018 & 2019 & Average & $\begin{array}{l}\text { RO } \\
\mathrm{E}\end{array}$ \\
\hline CU SRI & $\begin{array}{l}356,735 . \\
78\end{array}$ & $\begin{array}{l}425,825 . \\
60\end{array}$ & $\begin{array}{l}391,280.6 \\
9\end{array}$ & $\begin{array}{l}690,000.0 \\
0\end{array}$ & $\begin{array}{l}750,000 . \\
00\end{array}$ & $\begin{array}{l}720,000 . \\
00\end{array}$ & $\begin{array}{r}0.5 \\
91\end{array}$ \\
\hline $\begin{array}{l}\text { CU } \\
\text { KsTU }\end{array}$ & $\begin{array}{l}835,161 . \\
07\end{array}$ & $\begin{array}{l}974,600 . \\
39\end{array}$ & $\begin{array}{l}904,880.7 \\
3\end{array}$ & $\begin{array}{l}1,017,771 \\
.60\end{array}$ & $\begin{array}{l}1,614,85 \\
1.74\end{array}$ & $\begin{array}{l}1,316,31 \\
1.67\end{array}$ & $\begin{array}{r}0.7 \\
40\end{array}$ \\
\hline $\begin{array}{l}\mathrm{CU} \\
\mathrm{KATH} \\
\mathrm{CU}\end{array}$ & $\begin{array}{l}1,160,68 \\
6.06\end{array}$ & $\begin{array}{l}546,299 . \\
08\end{array}$ & $\begin{array}{l}853,492.5 \\
7\end{array}$ & $\begin{array}{l}1,342,200 \\
.47\end{array}$ & $\begin{array}{l}1,819,72 \\
2.80\end{array}$ & $\begin{array}{l}1,580,96 \\
1.64\end{array}$ & $\begin{array}{r}0.3 \\
46\end{array}$ \\
\hline $\begin{array}{l}\text { Ramse } \\
\text { yer }\end{array}$ & $\begin{array}{l}339,287 . \\
89\end{array}$ & $\begin{array}{l}102,363 . \\
57\end{array}$ & $\begin{array}{l}220,825.7 \\
3\end{array}$ & $\begin{array}{l}1,813,735 \\
.83\end{array}$ & $\begin{array}{l}2,145,17 \\
6.86\end{array}$ & $\begin{array}{l}1,979,45 \\
6.35\end{array}$ & $\begin{array}{r}0.0 \\
52\end{array}$ \\
\hline $\begin{array}{l}\text { S\&LSin } \\
\text { api }\end{array}$ & $\begin{array}{l}905,339 . \\
00 \\
-\end{array}$ & $\begin{array}{l}3,150,32 \\
1.00\end{array}$ & $\begin{array}{l}2,027,830 \\
.00 \\
-\end{array}$ & $\begin{array}{l}10,202,23 \\
5.00\end{array}$ & $\begin{array}{l}13,352,5 \\
55.00\end{array}$ & $\begin{array}{l}11,777,3 \\
95.00\end{array}$ & $\begin{array}{r}0.2 \\
67\end{array}$ \\
\hline $\begin{array}{l}\text { S\&LOp } \\
\text { port } \\
\text { RB }\end{array}$ & $\begin{array}{l}6,382,41 \\
0.00\end{array}$ & $\begin{array}{l}2,088,72 \\
6.00\end{array}$ & $\begin{array}{l}2,146,842 \\
.00\end{array}$ & $\begin{array}{l}34,054,52 \\
1.00\end{array}$ & $\begin{array}{l}41,724,5 \\
02.00\end{array}$ & $\begin{array}{l}37,889,5 \\
11.50\end{array}$ & $\begin{array}{r}0.0 \\
55\end{array}$ \\
\hline $\begin{array}{l}\text { Bosom } \\
\text { twe }\end{array}$ & $\begin{array}{l}1,308,88 \\
1.00\end{array}$ & $\begin{array}{l}156,996 . \\
00\end{array}$ & $\begin{array}{l}732,938.5 \\
0\end{array}$ & $\begin{array}{l}8,397,841 \\
.00\end{array}$ & $\begin{array}{l}7,998,23 \\
9.00\end{array}$ & $\begin{array}{l}8,198,04 \\
0.00\end{array}$ & $\begin{array}{r}0.0 \\
19\end{array}$ \\
\hline $\begin{array}{l}\text { RBOtu } \\
\text { asikan }\end{array}$ & $\begin{array}{l}1,002,57 \\
2.00\end{array}$ & $\begin{array}{l}1,354,19 \\
5.00\end{array}$ & $\begin{array}{l}1,178,383 \\
.50\end{array}$ & $\begin{array}{l}1,102,462 \\
.00\end{array}$ & $\begin{array}{l}2,225,09 \\
2.00\end{array}$ & $\begin{array}{l}1,663,77 \\
7.00\end{array}$ & $\begin{array}{r}0.8 \\
14\end{array}$ \\
\hline $\begin{array}{l}\text { RBAhaf } \\
\text { oAno }\end{array}$ & $\begin{array}{l}631,151 . \\
00\end{array}$ & $\begin{array}{l}736,399 . \\
00\end{array}$ & $\begin{array}{l}683,775.0 \\
0\end{array}$ & $\begin{array}{l}1,934,650 \\
.00\end{array}$ & $\begin{array}{l}2,510,30 \\
0.00\end{array}$ & $\begin{array}{l}2,222,47 \\
5.00\end{array}$ & $\begin{array}{r}0.3 \\
31\end{array}$ \\
\hline $\begin{array}{l}\text { RBMpo } \\
\text { nua }\end{array}$ & $\begin{array}{l}1,353,95 \\
8.00\end{array}$ & $\begin{array}{l}1,267,60 \\
0.00\end{array}$ & $\begin{array}{l}1,310,779 \\
.00\end{array}$ & $\begin{array}{l}5,811,291 \\
.00\end{array}$ & $\begin{array}{l}3,731,88 \\
3.00\end{array}$ & $\begin{array}{l}4,771,58 \\
7.00\end{array}$ & $\begin{array}{r}0.2 \\
66\end{array}$ \\
\hline CB GCB & $\begin{array}{l}343,079 . \\
00\end{array}$ & $\begin{array}{l}406,137 . \\
00\end{array}$ & $\begin{array}{l}374,608.0 \\
0\end{array}$ & $\begin{array}{l}1,325,417 \\
.00\end{array}$ & $\begin{array}{l}1,652,05 \\
4.00\end{array}$ & $\begin{array}{l}1,488,73 \\
5.50\end{array}$ & $\begin{array}{r}0.2 \\
73\end{array}$ \\
\hline $\mathrm{CB}$ & $38,680.0$ & 172,060 & $105,370.0$ & $631,740.0$ & 803,800 & $17,770.0$ & 0.2 \\
\hline Access & 0 & 00 & 0 & 0 & 00 & 0 & 40 \\
\hline & 152,185 & 226,372 & $189,278.5$ & $764,572.0$ & $960,867$. & $862,719$. & 0.2 \\
\hline $\begin{array}{l}\text { CB Cal } \\
\text { CB }\end{array}$ & 00 & 00 & 0 & 0 & 00 & 50 & 62 \\
\hline $\begin{array}{l}\text { Univers } \\
\text { al }\end{array}$ & $\begin{array}{l}44,049.0 \\
0\end{array}$ & $\begin{array}{c}40,053.0 \\
0\end{array}$ & $1,998.00$ & $\begin{array}{c}246,239.0 \\
0\end{array}$ & $\begin{array}{c}450,168 . \\
00\end{array}$ & $\begin{array}{c}348,203 \\
50\end{array}$ & $\begin{array}{r}0.1 \\
15\end{array}$ \\
\hline
\end{tabular}


INTERNATIONAL JOURNAL OF ACADEMIC RESEARCH IN BUSINESS AND SOCIAL SCIENCES Vol. 11, No. 7, 2021, E-ISSN: 2222-6990 @ 2021 HRMARS

$153,069, \quad 188,597, \quad 170,833,5 \quad 641,825,7 \quad 829,964, \quad 735,895, \quad 0.2$

\begin{tabular}{llllllll} 
CB UBA & 753.00 & 425.00 & 89.00 & 40.00 & 671.00 & 205.50 & 56 \\
\hline
\end{tabular}

$\mathrm{CU}=$ Credit Union; S\&L=Savings and Loans; SRI=Soils Research Institute; RB=Rural Bank; $\mathrm{CB}=$ Commercial Bank; KATH=Komfo Anokye Teaching Hospital; Opport=Opportunity International; KsTU=Kumasi Technical University 